\title{
Studies of Horned Curassow Pauxi unicornis in Bolivia
}

\author{
GUY COX, J. M. READ, R. O. S. CLARKE and V. S. EASTY
}

\begin{abstract}
Summary
Observations of the Horned Curassow Pauxi unicornis in Amboró National Park, depto. Santa Cruz, Bolivia, allowed us to assess the status of a species whose habits in the wild were virtually unknown. Vocalizations, including call notes and the deep booming song, are described. Density was estimated by counting booming birds in the breeding season using a three-hide triangulation method. The study showed birds to be aggregated in one part of the study area. A nest of was found and the incubating female was observed for nine days: the individual incubated alone, left the nest at night, and returned at first light.

Observaciones de la Pava Copete de Piedra (Pava Crista Azul) Pauxi unicornis en el Parque Nacional Amboró, depto. Santa Cruz, Bolivia, nos permitió evaluar el estado de una especie cuyo comportamiento en el ambiente silvestre es prácticamente desconocido. Se describen vocalizaciones, que incluyen notas de llamada "call notes" y el profundo canto de estampida "deep booming song." Se estimó la densidad de las aves por conteo de los sonidos de estampida "booming birds" durante la estación reproductiva, usando un método de triangulación con tres puestos de observación. Este estudio mostró que las aves se agregaban en una parte del área del estudio. Se encontró un nido de Pauxi unicornis y la hembra fue observada durante nueve días durante la incubación; la hembra incubaba sóla, dejaba el nido por la noche y regresaba a las primeras horas del amanecer.
\end{abstract}

\section{Introduction}

From 1987 through 1990 we made observations on the ecology and status of the Horned Curassow Pauxi unicornis unicornis in Amboró National Park, depto. Santa Cruz, Bolivia. Our goal was to determine the habitat requirements and population status of a species considered to be "highly vulnerable" (Collar and Andrew 1988). No information on this species in the wild had been published prior to our preliminary findings (Cox and Clarke 1988a), and until then the species had not been known from depto. Santa Cruz (Remsen and Traylor 1989).

Bond and Meyer de Schauensee (1939) described the species Pauxi unicornis from a pair of adult birds collected by M. A. Carriker in depto. Cochabamba, Bolivia. The specimen differed from Pauxi pauxi of Colombia and Venezuela in casque shape, tightly curled neck feathers and green instead of blue plumage sheen. These differences led the authors to consider $P$. unicornis a separate species because no intermediates were known in the great distance separating the two populations. Wetmore and Phelps (1943) described a new taxon from Venezuela, $P$. pauxi gilliardi, which they considered intermediate between pauxi and unicornis. They and some other authors (Bond and Meyer de Schauensee 1943, Vuilleumier 
Table 1. Locality records of Horned Curassow

\begin{tabular}{|c|c|c|}
\hline Locality & & Source \\
\hline \multicolumn{3}{|l|}{ Peru } \\
\hline 1 & $\begin{array}{l}\text { Cerros de Sira, depto. Huánuco }\left(9^{\circ} 26^{\prime} \mathrm{S}\right. \\
\left.74^{\circ} 45^{\prime} \mathrm{W}\right)\end{array}$ & $\begin{array}{l}\text { Two new specimens of race koepckeae } \\
1969 \text { (Collar et al. 1992) }\end{array}$ \\
\hline 2 & $\begin{array}{l}\text { Cerros de Távara, depto. Puno }\left(13^{\circ} 30^{\prime} S\right. \\
\left.69^{\circ} 41^{\prime} \mathrm{W}\right)\end{array}$ & $\begin{array}{l}\text { Sight record T. A. Parker } 1992 \text { (Collar } \\
\text { et al. 1992) }\end{array}$ \\
\hline \multicolumn{3}{|l|}{ Bolivia } \\
\hline 3 & $\begin{array}{l}\text { Hills above Bolivar, near El Palmar, } \\
\left.\text { depto. Cochabamba ( } 17^{\circ} 06^{\prime} S 65^{\circ} 29^{\prime} \mathrm{W}\right)\end{array}$ & $\begin{array}{l}\text { Species first discovered from pair of } \\
\text { specimens } 1937 \text { (coordinates from } \\
\text { Paynter 1992) }\end{array}$ \\
\hline 4 & $\begin{array}{l}\text { Guanay, Arepucho, depto. Cochabamba } \\
\left(17^{\circ} 18^{\prime} S 65^{\circ} 13^{\prime} W^{a}\right)\end{array}$ & $\begin{array}{l}\text { Specimens from late } 1960 \text { / early } 1970 \text { s. } \\
\text { Precise locality uncertain (Collar et al. } \\
\text { 1992) }\end{array}$ \\
\hline 5 & $\begin{array}{l}\text { Río Surutú, Amboró National Park } \\
\left(17^{\circ} 42^{\prime} S 63^{\circ} 44^{\prime} \mathrm{W}\right)\end{array}$ & This study \\
\hline
\end{tabular}

a Location of Guanay, Arepucho, is not clear. However, a Comunidad Guanay on the Rio Ivirizu, approximately $7 \mathrm{~km} \mathrm{NNW}$ of Arepucho, is indicated on the Instituto Geográfico Militar 1:250,000 map of the area, and coordinates are given for there.

1965) treated unicornis as a subspecies of pauxi, but Vaurie (1967) considered unicornis a distinct species. Weske and Terborgh (1971) reported the important discovery of a distinctive subspecies of Pauxi in central Peru, Pauxi unicornis koepckeae, which they considered to be closer to unicornis than to pauxi (and gilliardi). Consequently they, and all subsequent authors (Delacour and Amadon 1973, Collar and Andrew 1988, Cox and Clarke 1988a) have treated pauxi and unicornis as separate species.

At $850-900 \mathrm{~mm}$ total body length, the Horned Curassow is one of the largest cracid species. Contour plumage of live birds observed in depto. Santa Cruz, Bolivia, in contrast to descriptions from museum specimens (Bond and Meyer de Schauensee 1939), is black with a blue sheen lacking in the primaries. The belly, thigh tufts and under-tail coverts are white and the tail is broadly tipped white. The distinctive casque or horn projects vertically $63 \mathrm{~mm}$ from the forehead (distal measurement of Museo de Historia Natural "Noel Kempff Mercado", Santa Cruz, Bolivia, uncatalogued specimen). Other soft-part colours as seen in the field are bill salmon pink, maxilla narrowly blue basally where bill joins casque, and tarsi and toes light yellowish in males, pink in females. Feathers of crown and nape are tightly curled and lacquered, giving the feathers a shiny appearance (Cox and Clarke 1988a).

\section{Distribution}

The Horned Curassow occurs on the eastern slopes of the Andes from 500 to $1,500 \mathrm{~m}$ in deptos. Santa Cruz and Cochabamba, Bolivia. Scattered collection records (Table 1) have yielded a total of three museum specimens from depto. Cochabamba. The western extent of the Horned Curassow is not yet known with certainty but T. A. Parker's recent sighting of the species in Andean foothills on 


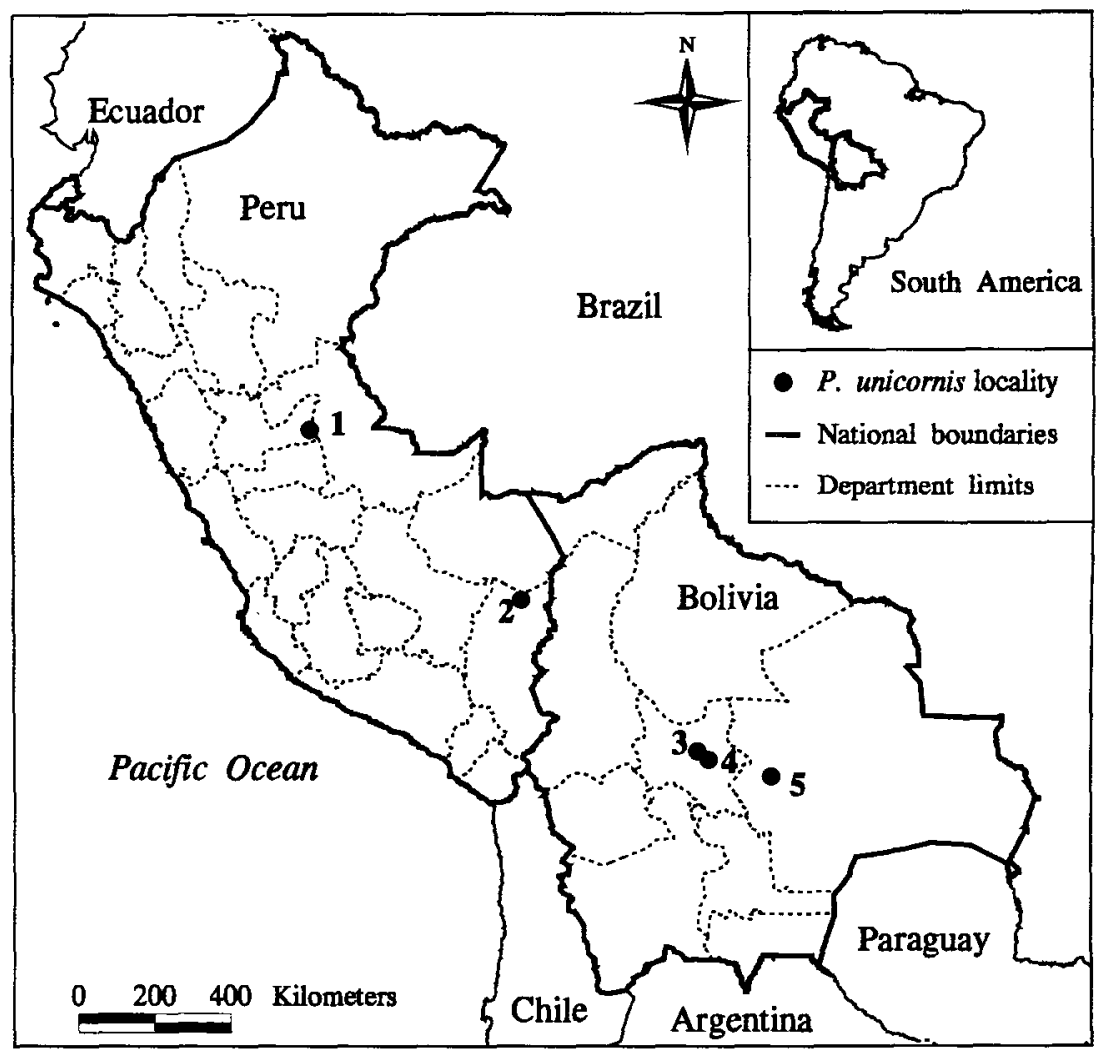

Figure 1. Distribution of Horned Curassow based on locality records (see Table 1 for locality information).

the Río Távara, depto. Puno, in extreme south-eastern Peru (Collar et al. 1992) shows that it probably occupies continuous habitat in the Bolivian Andes from Amboró National Park westward, at least into southern Peru, although the species has yet to be recorded in depto. La Paz, Bolivia (Figure 1).

\section{Habitat}

The Horned Curassow inhabits steep and densely forested foothill slopes of the eastern Andes. The study site near the head of the main Río Saguayo valley inside Amboró National Park (Figure 1; locality 5) was characterized by extremely steep ridge and valley terrain cut by steep-sided streams. High cliffs bounding the head of the valley made for spectacular waterfalls. Frequent rock falls from these cliffs produced scree slopes that merged into boulder-filled successional growth. The vegetation of the region was a mosaic of secondary and mature stands, with mature forest found only in relatively small expanses of flat land far from the cliffs. Some Horned Curassows were seen in tall interior forest and disturbed forest edge but most sightings were made in tall secondary growth inside forest. 


\section{Methods}

\section{Status}

In the months of study after first discovering Horned Curassows on the south side of the upper Río Saguayo valley (Cox and Clarke 1988b), selected tracts of forest were walked and exploratory visits to new areas were made in the hope of seeing the species. Numerous encounters with individuals and groups of birds in the field, and continued searches that covered every month of the year over a three-year period, allowed us to assess status and seasonal movements (or detectability).

\section{Vocalizations}

Notes of vocalizations were taken when curassows were observed in the field. In addition, we conducted a study of Horned Curassow's booming behaviour from 28 October to 4 December 1988 , principally to estimate population density. It became clear while collecting field data that the species was present in unusually large numbers, so the three-hide triangulation and single-hide studies (see below for methods) were redirected to quantify this apparent aggregation and to describe the booming sessions we heard.

\section{Density}

Numbers of booming males were estimated in the daytime in the steep-sided valley of the Quebrada Ancha, a tributary of the upper Río Saguayo, by a three-hide triangulation method. Three temporary hides were made, $150 \mathrm{~m}$ apart, forming an equilateral triangle in a study area of approximately 60 ha, bounded on two sides by steep ridges beyond which we could not hear curassows. Observers at each hide recorded time, estimated distance and direction of booms heard. Time interval between successive boom syllables was also recorded in a few cases. Distance to booming birds was estimated to $\pm 100 \mathrm{~m}$ from prior experience in tracking down booming birds, on a six-point scale:

1. $(350 \mathrm{~m})$ Very distant; only final syllable audible

2. $(250 \mathrm{~m})$ Distant; final syllable clear, other syllables barely audible

3. (200 m) Middle-distance; all phrases clear

4. $(100 \mathrm{~m})$ Close; syllables distinct

5. $(50 \mathrm{~m})$ Very close; low resonant notes clear

6. Visible from hide

Note that the maximum distance of $450 \mathrm{~m}(350 \pm 100 \mathrm{~m})$ was the approximate radius of the 60 ha study site. Direction was estimated to within $15^{\circ}$ from markers set out in $60^{\circ}$ increments. Duration of watches was six hours, from o6hoo to 12hoo, for five days.

Data from the three-hide triangulation watches were simplified by discarding all records of under 10 minutes, thus excluding single or doubtful records, to give a dataset of substantial, well-defined boom sessions. The positions ( $\pm 100 \mathrm{~m}$ ) of booming individuals were plotted daily using the three-hide data. It was 
Table 2. Daily numbers of booming Horned Curassows calculated from three-hide triangulation surveys. Booming sessions less than 10 minutes duration not included. $x_{\max }=$ maximum potential number of individuals recorded; $x_{\min }=$ minimum potential number of individuals recorded; daily means $(\bar{x})=\left(x_{\max }+x_{\min }\right) / 2$

\begin{tabular}{cccc}
\hline Day & $x_{\max }$ & $x_{\min }$ & $\bar{x}$ \\
\hline 1 & 12 & 6 & 9 \\
2 & 16 & 8 & 12 \\
3 & 16 & 10 & 13 \\
4 & 18 & 8 & 13 \\
5 & 17 & 7 & 12 \\
Total & 79 & 39 & 59 \\
\hline
\end{tabular}

expected that data-points would coincide in time, distance and direction when the same bird was heard booming by more than one observer. Because this happened on relatively few occasions, probably due to difficulties of estimating distance to the booming bird, the potential maximum and minimum number of birds were calculated for each day from points plotted on a map of the site (Table 2). Maxima $\left(x_{\max }\right)$ were the sum of all booming records. Minima $\left(x_{\min }\right)$ were determined by combining all data-points that could conceivably have been produced by the same bird. Daily means $(\bar{x})$ were thus calculated by: $\left(x_{\max }+\right.$ $\left.x_{\min }\right) / 2$.

Single-hide watches were made by only one observer, using the same method, principally to record booming frequency for hours of the day not covered by the three-hide watch. Single-hide observation periods were 18 hours (12hoo to o6hoo) for two days, and 12 hours (18hoo to o6hoo) for two days. Because night watches were made by one observer from a separate hide on the edge of the site, for fewer total hours, these data were not pooled with the three-hide data.

\section{Nesting behaviour}

One nest of Horned Curassow was found and subsequently observed for nine days (7-15 November 1989). Behavioural observations of the incubating bird were made through mounted $10 \times 50$ binoculars from a hide $40 \mathrm{~m}$ distant on the banks of the Río Saguayo, from first light to nightfall (o5h30 to 18h30). Behavioural activity was recorded with notebook and stopwatch to the nearest minute.

\section{Feeding}

We never observed Horned Curassows feeding. The diet of this species was inferred from food sources available when curassows were sighted, supplemented with examination of one faecal sample.

\section{Results}

\section{Status}

We found Horned Curassows to be fairly common in a narrow elevational range on the eastern slopes of Andean foothills within Amboró National Park. The 
species apparently favoured forest interior. Booming males were seen on perches on ridge-tops bordering secondary growth and groups of up to six birds were seen on flatter ground supporting tall forest. The lowest record was a pair of birds at $500 \mathrm{~m}$ elevation in thick successional growth on the side of the Rio Saguayo. Low records in river-edge vegetation are probably related to nest-building or nest-site selection.

We saw Horned Curassows mainly during the months late September to early January, which we interpreted either as elevational movements, perhaps following food availability, or an aggregation of birds during the breeding season. However, given that there are now many more sight records taken by park guards for other months from 1993 to 1996 (data not shown) that suggest that the birds are present all year in Amboró National Park, our results may be better attributed to differences in detectability due to increased vocalizations during the breeding season.

\section{Vocalizations}

We recorded two vocalization types, which can be categorized as alarm calls, given when potential danger is detected, and booming song, given during the breeding season, October to December.

Alarm calls The alarm call of Horned Curassów is an explosive, disyllabic "K-Sop!". The call is given from a perch after the bird flushes from the ground and is accompanied by rapid flicking outward of the tail at the "Sop!". This action draws attention to the white tail tips, especially when the bird is seen from below. Tail-flicking behaviour seems to be common to all cracids as an indication of anxiety (Delacour and Amadon 1973). In our observations of Horned Curassows the call was typically repeated about every one to two seconds for up to an hour when, at certain times of the year, alarmed birds would fly up to a perch but make little further attempt to distance themselves from us.

Song or boom The song or booms of curassows are part of reproductive behaviour. Males normally boom continuously for several hours each day from a perch at low to mid-levels at forest edge. Two individuals were observed booming on an exposed mound on the ground by the side of streams. We call the four-phrase vocalization a "boom" (Figure 2a), the repetitions of which comprise "booming sessions". The emphatic final "HMM!" is the loudest part of the boom and is audible at a much greater distance than the other syllables.

In Amboró National Park the Horned Curassow is sympatric with one other large curassow, the Greater Razor-billed Curassow Mitu tuberosa, primarily a bird of lowland forest that narrowly overlaps with Pauxi from approximately 500 to $1,000 \mathrm{~m}$ elevation. The booming vocalizations of the two species are similar but differ in the third phrase; $M$. tuberosa has a distinctive three-syllable "Hm-mm-mm", which in P. unicornis is a less-defined, rising, two note "Hmm-mmum" (Figure 2a,b). Male M. tuberosa boomed earlier in the year (August 

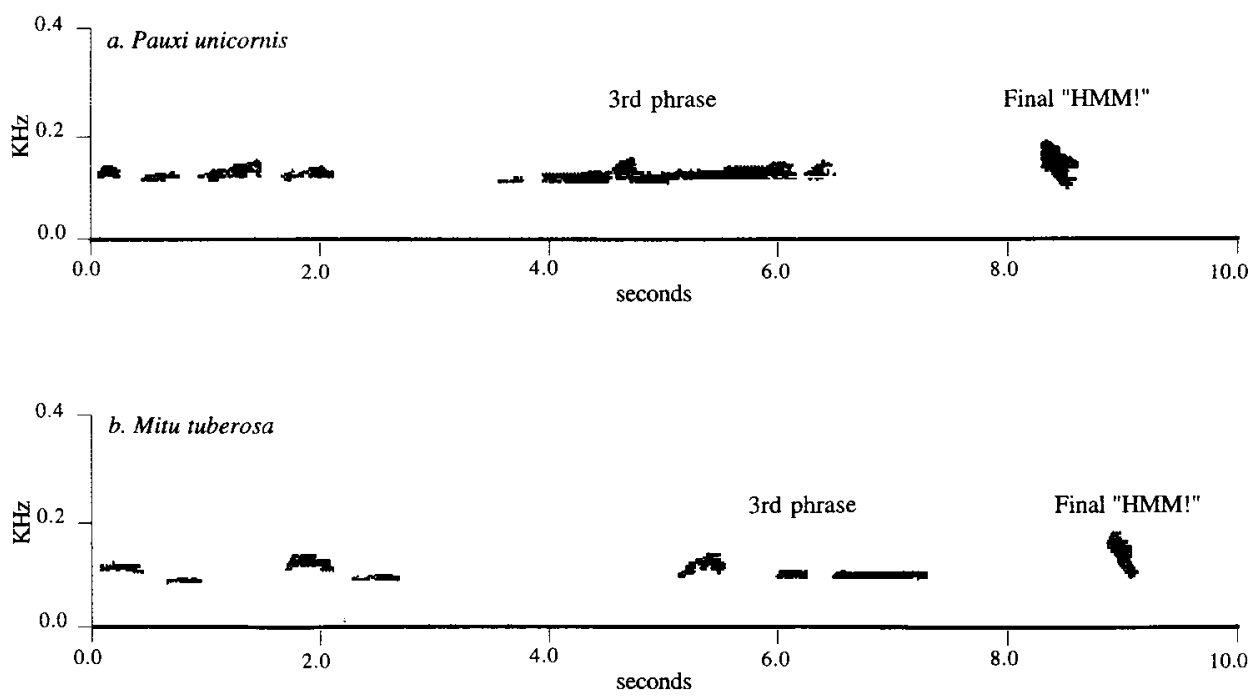

Figure 2. Sonograms showing boom phrases of Horned Curassow and Greater Razorbilled Curassow: songs of the two species are similar but differ in the third phrase.

to September) compared with P. unicornis (October to December) with no recorded seasonal overlap.

Booming sessions The three-hide and single-hide observations gave a total of 75.5 hours (in 78 sessions) and 15.25 hours (in $4^{8}$ sessions) of boom sessions longer than 10 minutes, respectively. Mean session duration was 58.1 minutes $(\mathrm{SD}=$ 56.66), the longest session being 4 hours 11 minutes. The two datasets combined (Figure 3) show that booming occurred during 14 hours 50 minutes of the 24 hour cycle. Peak booming times were approximately 04 hoo and o7hoo; these peaks, however, may reflect observer fatigue close to the change-over in watches (o6hoo) and may indicate a single dawn peak in booming activity between o4hoo and ophoo.

Plotting the intervals between successive final syllables of the last 20 minutes of a Horned Curassow session (Figure 4) revealed much variation in boom interval. Whereas the first three phrases of a boom were given stereotypically (i.e. with no variation in pitch or duration), the final syllable, the emphatic "HMM!", was often omitted or delayed. Longer intervals between final "HMM!"s occurred in three distinct groups (Figure 4, marked a, b and c). Modal final "HMM!" interval $(n=127)$ was 15 seconds (Figure 5$)$. The lack of a second peak at 30 seconds implies that the session is composed not simply of units with or without a final syllable but is more complex.

In the case of curassows, it seems likely that the booming sound is produced by the passive extrusion of air through the trachea by contraction of muscles on air sacs in the neck that compress the lungs. We observed pumping motions of the head prior to booming in Horned Curassows in the field, which agrees with P. Schwartz's and others' accounts (in Delacour and Amadon 1973) of pumping motions of the head and inflation of the neck prior to booming in captive and 


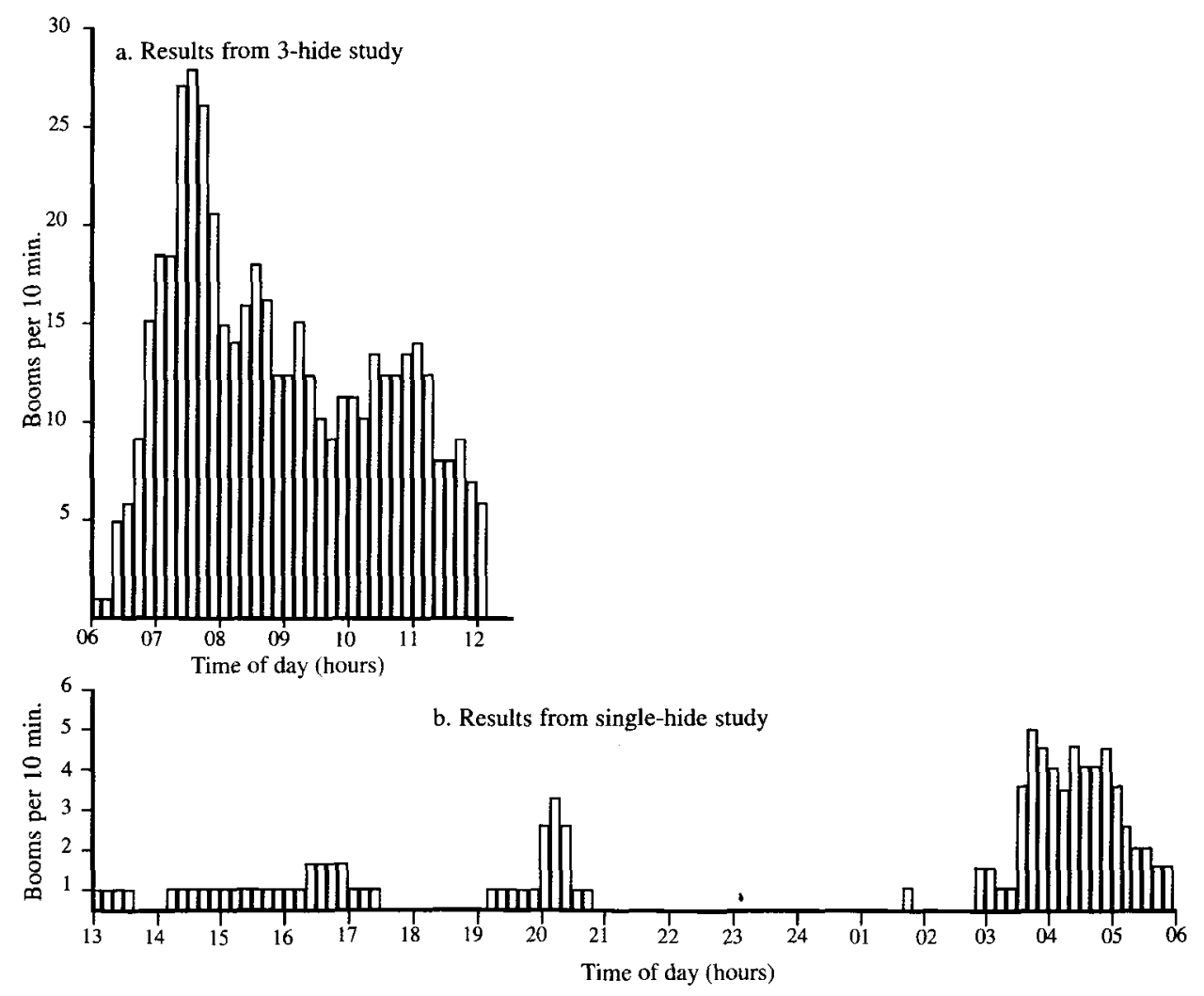

Figure 3. Daily rates of booming of Horned Curassow.

wild birds of several species of cracids. We likewise observed that booming was accomplished with the bill closed, a characteristic also noted by others (in Delacour and Amadon 1973).

Booming between two individuals was synchronous; the final syllable of one bird was given about 1 second after the other for extended periods. Synchrony occurred between the recorded bird and another in $71 \%$ of final syllables (Figure 4). Our field notes recorded that "synchrony is a noticeable event and is easily distinguished from other, unsynchronized booming". Synchronized booming would go on for approximately half an hour after which the synchronizer (individual that started to boom later) would continue, and the first booming bird stop.

\section{Density}

The mean number of booming birds for the study period was 0.2 per ha per day, or one bird per 5 ha. However, birds were not distributed evenly over the site: $54 \%$ of individuals were recorded in only $13 \%$ of the area. Density of booming birds in the south-eastern part of the site was estimated at 1 per ha. Using the 


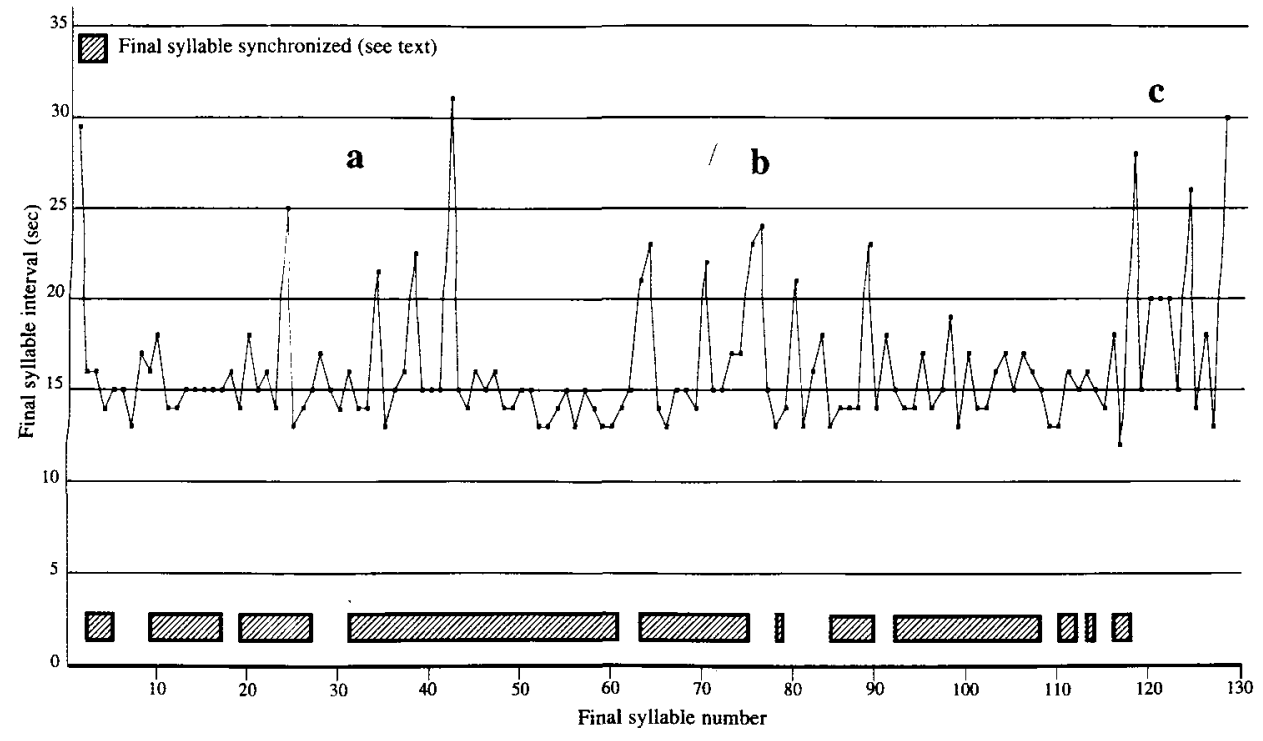

Figure 4. Progression of Horned Curassow boom session showing relative time between consecutive "HMM!'s or final syllables as an indication of song rate. a, b and c are periods when the final syllable was repeatedly omitted or delayed.

mean density estimate for booming birds, each spent an average of 77 minutes per day booming.

In 1990 lower densities of booming Horned Curassows were observed. Indeed, booming was heard infrequently and individuals were encountered much less frequently than in 1989. Such annual variation in density suggests that birds were following an unpredictable food source, such as supra-annual or environmentally cued fruit set.

\section{Nesting}

One nest was found, it was a bowl $30 \mathrm{~cm}$ in diameter, contained a single egg and was placed at $5 \mathrm{~m}$ in the major fork of a low $(9 \mathrm{~m})$ tree growing on a small island of vegetation at the confluence of a wide stream with the Río Saguayo. The nest site, surrounded by water only after heavy rain runoff from rocky overflow channels, was composed of a small group of trees and bushes, with a ground cover of ferns and other secondary vegetation. It was isolated from the nearest forest-edge vegetation by the approximately 4 -m-wide overflow streambed of shingle and rocks.

The bird would leave the nest some time during the night and return near dawn (before o6hoo), crossing from the continuous forest edge at its nearest point to the island. The incubating bird generally sat quietly on the nest throughout the morning. The sleeping posture, with head tucked into the wing, was rarely seen and when it did occur, it was for less than 5 minutes at a time. This posture was probably a response to insects; large tabanid flies flew repeatedly round the 


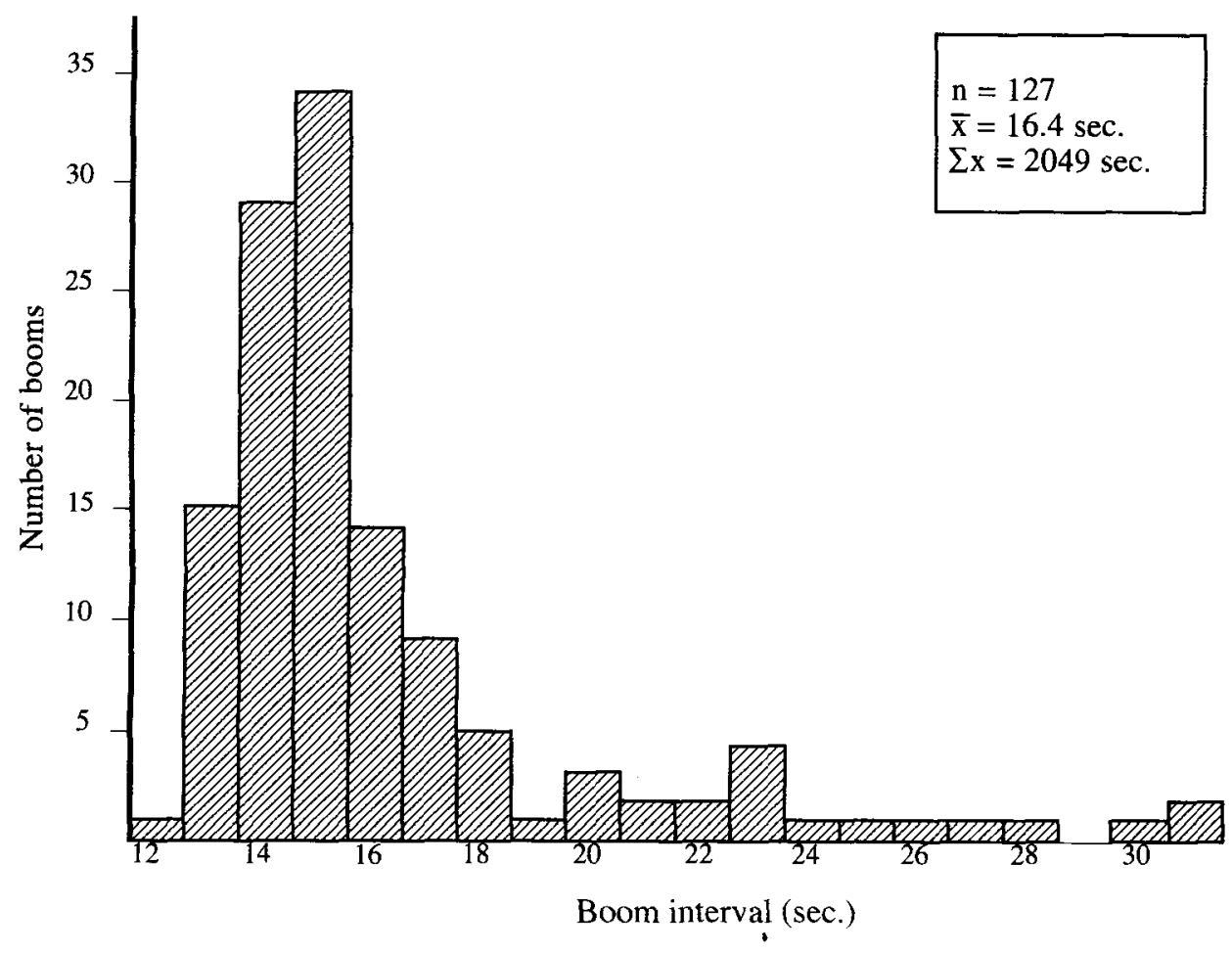

Figure 5. Histogram of final boom syllable frequency in Horned Curassow booming session.

bird's head and a head flick was given in response to flies landing on the head or neck. On several occasions the bird actually took the insects on the wing, an activity usually followed by a "chewing" motion. "Chewing" (repeated opening and closing of the bill) and yawning (single opening of bill to its widest extent) were also observed as independent actions.

In the afternoons activity increased, and the bird seemed to become restless. Preening bouts, first while the bird sat or squatted on the nest, began around 15 hoo and increased in intensity throughout the afternoon. By 16 hoo to 18 hoo frequent bouts of preening while standing, and scratching of the face with the middle toenail, were interspersed with attention to the nest. This last behaviour included addition of both fresh leaves picked from surrounding vegetation and repositioning of dead leaves, pecking at and arranging sticks inside the nest, and a motion that we called "look in nest" that may have included egg-rolling. As we ended our daily watches, the bird was still actively engaged in preening and nest attention and we did not see the bird move off the nest in the evening. We were unable to continue observations to the hatching of the egg.

Pink leg colour indicated that the bird was female. That only females incubate in cracids is well known from captive breeding of various species (Delacour and Amadon 1973) and was a confirmation of this previously undocumented sexual dimorphism in Horned Curassows. The bird incubated alone and was not visited 
by a mate in the 9 days of the study. Careful searches inside the forest near the nest failed to reveal the presence of an accompanying male.

\section{Feeding}

Curassows are principally terrestrial frugivores but some species feed on insects and even small vertebrates (Delacour and Amadon 1973). We never observed Horned Curassows feeding but it is possible that fruits of the genus Ficus (Lauraceae) formed an important part of the diet of the birds observed. These fruits were abundant on the ground in many places where Horned Curassows were seen. One faecal sample collected after a bird defecated contained small Ficus-like seeds in an otherwise homogeneous brown mass.

\section{Discussion}

It is a matter of some contention, owing in part to the large proportion of mating observations made on captive birds, as to whether any curassows are polygamous in the wild. Delacour and Amadon (1973) stated that Schaefer's assertion that some species of curassow are polygamous in the wild is "contrary to everything that is known of their breeding in captivity".

Our observations suggest either that Horned Curassows are polygamous, or that breeding occurs during aggregation of monogamous pairs. The large number of (presumed) males on the study site may have represented a lek, where males compete for females by booming and possibly engage in courtship displays (although we have not observed these) similar to those described by Beebe (in Delacour and Amadon 1973) in Black Curassow Crax alector. However, aggregation may simply be a response to seasonal food availability i.e. the local population may be nomadic. Birds moving in response to fruit availability and, at the appropriate time, reproducing wherever they happen to be would give the advantage of ensuring that young are raised in the most productive area in an environment where fruit availability may be seasonally unpredictable.

The question also remains as to whether Horned Curassows disperse after the breeding season, with some remaining on the site, which would imply that the aggregation is for breeding purposes only, or whether all individuals leave, which would mean that seasonal movement occurs in response to some other resource. Answering this question is confounded by seasonal variation in detectability. During the breeding season males may be tracked down by their booming, when they do not seem very aware of approach. Some observers have noted that some curassows enter a "trance-like state" when booming (Beebe in Delacour and Amadon 1973). When pairs were disturbed at this time, they emitted easily identifiable call notes and may remain in the vicinity. A single (presumed) female performed a distraction display, similar to that described by Delacour and Amadon (1973), running past us back and forth on the ground repeatedly and then flying away a few feet to return, making noisy crash-landings in front of us, for half an hour in late November. We assumed that chicks were present but were not able to find them. All in all, Horned Curassows were relatively easily seen and heard during the reproductive phase. 
Those few sightings made in the non-breeding season in September, October and January differed. Birds either flew a long distance away from us, usually without any alarm call and we were not able to locate them subsequently, or they walked silently away into undergrowth. Such behaviour definitely biased our perception of the seasonal density of the species on the study site. Recent data (from park guards and others) show Horned Curassows to be present all year.

The Horned Curassow has been recommended for IUCN red data category of Vulnerable (IUCN/SCC 1995). Long-term survival of the species depends on adequate management of the protected areas Parque Nacional Amboró, Parque Nacional Carrasco, and Parque Nacional Pilón Lajas, which currently ostensibly protect the majority of the species's distribution in Bolivia. Amboró National Park was reduced by over 150,000 ha (from c. 600,000 to 450,000 ha) in 1995 , cutting off virtually all lowland areas and cloud forest areas to the south. Our study site is just inside the new limits. Amboró is now being managed by Fundación Amigos de la Naturaleza (Santa Cruz, Bolivia), which is preparing a management plan to be financed by The Nature Conservancy and which should be available by the end of 1996. Parque Nacional Carrasco has no management plan, and the status of Parque Nacional Pilón Lajas is unclear.

\section{Acknowledgements}

Support for the Horned Curassow Project was provided by the Peter Moores Foundation, Sir David Attenborough, II International Cracid Symposium, the German Ornithological Society, World Pheasant Association, Queen Mary Westfield College, University of London, Nathan Turner Charitable Trust, British Petroleum, 27 Foundation, James Clements, Whitley Animal Protection Trust and Morag, Graham and James of BTAM. In addition we thank Ing. Esteban Cardona, Lic. Arturo Moscoso, Ing. Italo Cabruja, Paolo Bettella, Esteban Llanos, Clemente Cruz, Oliver Greenfield, Ben Cornwell, Stuart Strahl, Francois Sagot, Nicolas Renaudin, Barbara Johnstone, and Manuel Marín. Earlier manuscripts of this paper were greatly improved by the valuable comments of $\mathrm{J}$. $\mathrm{V}$. Remsen, Tom Schulenberg and Nigel Collar.

\section{References}

Bond, J. and Meyer de Schauensee, R. (1939) Descriptions of new birds from Bolivia, Part II. A new species of the genus Pauxi. Notulae Naturae 29: 1-4.

Bond, J. and Meyer de Schauensee, R. (1943) The birds of Bolivia, Part 2. Proc. Acad. Nat. Sci. 95:180.

Collar, N. J. and Andrew, P. (1988) Birds to watch: the ICBP world check-list of threatened birds. Cambridge, U.K.: International Council for Bird Preservation (Tech. Publ. 8).

Collar, N., Gonzaga, L. P., Krabbe, N., Madrono Nieto, A., Naranjo, L. G., Parker, T. A. III, and Wege, D. C. (1992) Threatened birds of the Americas: The ICBP/IUCN Red Data Book. 3rd edition, part 2. Cambridge, U.K.: International Council for Bird Preservation, pp 152-153.

Cox, G. and Clarke, R. O. S. (1988a) Erste Ergebnisse einer Studie über den Bolivianischen Helmhokko Pauxi unicornis im Amboró-Nationalpark, Bolivien. Trochilus 9: 96-101.

Cox, G. and Clarke, R. O. S. (1988b) In search of the unicorn. World Pheasant Assoc. News 19: 21-22. 
Delacour, J. and Amadon, D. (1973) Curassows and related birds. New York: American Museum of Natural History.

IUCN/SCC (1995) Conservation assessment and management plan for Neotropical Guans, Curassows, and Chachalacas, eds. S. Strahl, S. Ellis, O. Byers and C. Plasse. Apple Valley, Minn.: IUCN/SCC Conservation Breeding Specialist Group.

Paynter, R. A. (1992) Ornithological gazetteer of Bolivia, 2nd edition. Cambridge, Mass: Harvard University.

Remsen, J. V., Jr and Traylor, M. A., Jr. (1989) An annotated list of the birds of Bolivia. Vermillion, S.D.: Buteo Books.

Vaurie, C. (1967) Systematic notes on the bird family Cracidae, 10. The genera Mitu and Pauxi and the generic relationships of the Cracini. American Mus. Novitates 2307: 1-20.

Vuilleumier, F. (1965) Relationships and evolution within the Cracidae (Aves, Galliformes). Bull. Mus. Comp. Zool. 134: 1-27.

Weske, J. S. and Terborgh, J. W. (1971) A new subspecies of curassow of the genus Pauxi from Peru. Auk 88: 233-238.

Wetmore, A. and Phelps, W. H., Sr. (1943) Description of a third form of curassow of the genus Pauxi. J. Washington Acad. Sci. 33: 142-146.

\section{GUY COX}

Museum of Natural Science, 119 Foster Hall, Louisiana State University, Baton Rouge, LA 70803, U.S.A.

\section{JANE M. READ}

Dept. of Geography and Anthropology, 231 Howe-Russell, Louisiana State University, Baton Rouge, LA 70803, U.S.A.

\section{ROBIN O.S. CLARKE}

Casilla 2097, Santa Cruz, Bolivia.

\section{VALERIE S. EASTY}

101 Leighton Rd, Kentish Town, London, NW5, U.K. 